\section{NSF falls short on shortage}

\section{Washington}

A WIDELY publicized study by the National Science Foundation (NSF) forecasting a shortage of 675,000 scientists in the next two decades is so flawed as to be nearly worthless, a subcommittee of the US Congress has concluded. While the committee's year-long investigation into the issue - which culminated in a six-hour hearing last week - may have sullied NSF's reputation, it leaves unanswered the larger question of whether the nation is training a sufficient number of scientists to meet its needs in the next century (see page 548).

At issue is a 1987 study by NSF policy a $\mathrm{n}$ a 1 y $\mathrm{s} \mathrm{t}$ Peter House. It reaches the simple conclusion that a declining number of college-aged students also will mean fewer graduates trained in science and engineering. House drew an imaginary line from the record high level of science degrees awarded in 1984-86 and calculated the difference between that hypothetical level and the actual number of degrees awarded.

But labour economists and policy analysts say that the resulting number 675,000 between 1986 and 2006 - is meaningless. It cannot be called a shortage, they say, because a shortage requires an estimate of demand, which House did not attempt. In addition, the assumption that those graduates represent the supply of future scientists also ignores such factors as the existing labour pool of scientific talent working outside their field, the migration of workers into science and any changes in the proportion of undergraduates who choose to major in science. And because the number is an aggregate, it could mask important trends within specific fields. In short, say those experts, the number is wholly useless for its original purpose as a policy tool.

"The long-term accuracy of such predictions isn't sufficient to guide federal policy," testified John Andelin, an assistant director at the congressional Office of Technology Assessment. Asked about the wisdom of offering a single number, Andelin said, "if you want press attention, yes, it's useful. If you want intelligent discourse, the answer is no."

But that did not stop NSF from using it, according to the chairman of the investi- gations subcommittee of the House science committee that called the hearing. Representative Howard Wolpe (Democrat, Michigan) says that NSF officials, including its former director, Erich Bloch, cited that number repeatedly in testimony and speeches warning of a looming, serious shortage of scientists. The number helped NSF to gain a larger budget, Wolpe claims, and became part of legislation. For years, NSF officials stood by the number despite strong criticism from inside the statistical community, Wolpe pointed out. Although such tactics are commonplace in Congress, he added, "nobody expects NSF to play that game. Everyone around here assumes that NSF's numbers are good science."

House defended his study as nothing more than a theoretical exercise to understand the impact on science of the so-called 'baby bust' of the 1970s that followed the baby boom after the Second World War. He said he never intended it to be used as policy document and had "no way of knowing" whether it influenced policy-makers either inside or beyond NSF. The projected difference between the number of degrees awarded in the mid-1980s and the next two decades should be called a 'shortfall', he said, not a shortage.

Wolpe said that he found House's explanation "extraordinary". Referring to previous panels of experts that had attacked House's study as "pseudoscience" and "nonsense", Wolpe asked House at one point, "So you're saying that everybody who has testified here today wasn't understanding your study?"

Wolpe was also troubled by NSF's reluctance to acknowledge the persistent criticism of the House study. He said that internal NSF memoranda that refer to "protect[ing] the foundation from damage" and "losing this discussion" suggest that NSF officials were defending their mistakes rather than trying to correct them.

Walter Massey, who succeeded Bloch as director of NSF in March 1991, assured Wolpe that that was not the case. "I treat this as a very serious matter", Massey said, pointing to a new round of grants for research to improve the quality of the data on factors that affect scientific supply and demand.
Jeffrey Mervis
A European university

\section{London}

EUROPE needs a unified university system to solve the scientific and technical problems of the next century. The idea, offered at a conference last weekend on "Europe in the Third Millennium", came from Kai Simons of the European Molecular Biology Laboratory in Heidelberg and was received warmly by academics, civil servants and politicians. The event was organized by the Centre for European Studies at the University of Exeter.

"The present state of science in European universities is not encouraging," Simons says. "Piecemeal delivery of teaching without coordination, proliferation of sub-areas leading to narrow-minded specialization and lack of mobility, accompanied by stagnation and local in-breeding, are conspicuous ingredients in the activities of many science faculties. This lack of communication results in myopic research, filling scientific journals with papers that no one reads."

Simons suggested that a number of model faculties should be created to teach an integrated curriculum to students from around the world. Upon graduation, they would carry some sort of European quality stamp. "The intellectual effort to do this should come from the universities themselves, but the stimulus should come from Brussels," Simons said.

Although the participants supported the notion, there was some doubt about how effective such involvement might be.

"We need a committee in Brussels to pick the institutes which would become the models," commented Sir Eric Ash, rector of Imperial College, London, "but doing this would limit the freedom of the institutes to achieve the changes."

Others pointed to the success of informal agreements that have arisen below the bureaucratic water mark. At present, the European Commission cannot intervene in education policy as it can with research. However, programmes such as Erasmus and Tempus - designed to facilitate an interchange of students within Europe have had considerable influence on European education.

"Erasmus is a multiplying force for many things, such as curriculum change, which were not its purpose," said Theo Veenkamp, director of the European Community's Tempus office. "If it had been set out explicitly, there would have been a political uproar. We need innocent impulses from Brussels that will also act as a catalyst for the sort of changes we want, and let them evolve naturally," he said.

Such a scheme would cost a great deal, the conferees agreed. But they had plenty of suggestions about how to pay for it, including taking money from the EC's Common Agricultural Policy or the US manned space programme. Ian Mundell 